\title{
ON THE DIFFERENCE OF A CONTRACTION AND AN INVERSE STRONGLY MONOTONE OPERATOR
}

\author{
DINU TEODORESCU
}

Abstract. In this paper we prove a unique fixed point result in real Hilbert spaces for the difference operator $T-F$, where $T$ is a contraction and $F$ is an inverse strongly monotone operator.

Mathematics subject classification (2010): 47H05, 47H09, 47H10.

Keywords and phrases: Contraction, inverse strongly monotone operator, unique fixed point.

\section{REFERENCES}

[1] S. M. Alsulami, A. Latif And W. TaKahashi, Strong convergence theorems by hybrid methods for split feasibility problems in Hilbert spaces, J. Nonlinear Convex Anal. 16, 12 (2015), 2521-2538.

[2] F. E. BRowder AND W. V. Petryshyn, Construction of fixed points of nonlinear mappings in Hilbert space, J. Math. Anal. Appl. 20 (1967), 197-228.

[3] J. CHEN, L. ZHANG AND T. FAN, Viscosity approximation methods for nonexpansive mappings and monotone mappings, J. Math. Anal. Appl. 334 (2007), 1450-1461.

[4] K. Deimling, Nonlinear functional analysis, Springer Verlag, New York, 1985.

[5] H. IIDUKA AND W. TAKAHASHI, Strong convergence theorems for nonexpansive nonself-mappings and inverse-strongly-monotone mappings, J. Convex Anal. 11, 1 (2004), 69-79.

[6] R. I. KaChUROVSKI, On monotone operators and convex functionals, Uspekhi Mat. 15 (1960), 213 215.

[7] A. Petrusel, D. R. SAHU AND V. SAGAR, An extragradient iterative scheme for common fixed point problems and variational inequality problems with applications, An. Ştiinţ. Univ. Ovidius Constanţa, Ser. Mat. 23, 1 (2015), 247-266. 